\title{
PLUVIO-THERMAL CONDITIONS PERTAINING TO VEGETATION OF KEY CROPS IN SOUTHEASTERN POLAND 1901-2010
}

\author{
ZIERNICKA-WOJTASZEK, A. \\ Department of Ecology, Climatology and Air Protection, Faculty of Environmental Engineering \\ and Land Surveying, University of Agriculture in Kraków \\ Al. Mickiewicza 24/28, 30-059 Kraków, Poland \\ (e-mail:a.ziernicka-wojtaszek@ar.krakow.pl) \\ (Received $9^{\text {th }}$ Jul 2019; accepted $16^{\text {th }}$ Oct 2019)
}

\begin{abstract}
The aim of this article is to analyze the variability of current climate changes, as well as favorable and unfavorable trends in weather conditions for key crops in south-eastern Poland in the April-October period (1901-2010). The climate variability was analyzed for four time slices (climate normals): 1901-1930, 1931-1960, 1961-1990, and 1981-2010. The aforementioned slices include natural dry and wet cycles as well as cool and warm periods. Numerous weather bulletins and written accounts were used in this study, as well as mean area temperature values and precipitation totals. The data, especially from the last 30 years, implies that key crops will be less susceptible to heat related stress during spring months whilst becoming more susceptible to the precipitation deficit stress in the summer months (due to increased evaporation and the lack of a clear precipitation trend). The article also proves that climate analyses based on mean values recorded over an extended period of time are useful for characterizing current climate conditions in a historical context, but can neither be applied for forecasting purposes nor put to practical use.
\end{abstract}

Keywords: the Subcarpathian voivodeship, plant vegetation, climate change, pluvio-thermal conditions, global warming

\section{Introduction}

Due to natural climate variability, the characteristics that apply to resources, qualities and climatic hazards in a given region are assessed usually over a period of 30 years (climate normal recommended by the World Meteorological Organization). The World Meteorological Organization and its predecessor (the International Meteorological Organization) have initiated and coordinated the establishment of climate normals for its member states. This process started with the period 1901-1930 and continues today, with updates being made every 30 years such as 1931-1960, 1961-1990 (Arguez and Vose, 2011). This principle is not contradicted by long-term analyses of climate data as well as analyses of individual cases of extreme weather events that occur worldwide.

Owing to the clearly visible warming trend that has been observed in recent years and the intensifying process of global warming (Solomon et al., 2007; Milly et al., 2008) the idea to characterize current or future climate conditions by means of 30 year normals, is being questioned more and more often (Livezey et al., 2007). In the existing situation, in order to make the climate statistics more accurate, it becomes necessary to update climate normals not every 30 years, but every 10 years. For instance, instead of making 1991-2020 the next normal, the 1971-2000, and recently even 1981-2010 are being used. In order to obtain a broader temporal perspective, emission scenarios are elaborated by the IPCC (i.e. 2000 scenario), which are subsequently used by climate modelling centers as an integral component for predicting Earth's climate variability. 
Natural climate variability and contemporary climate change affect certain aspects of the environment and human economic activity. In agriculture they lead to fluctuations of meteorological conditions during the vegetation period, which result in crop variability (Křen, 1995; Motha and Baier, 2005). In the past, variable weather conditions which often led to extreme events caused numerous crop failures. Long time ago scholars drew up chronicles of natural hazards that affected the Polish nation. The work of Bujak (1976) which analyzes periods: 1450 to 1700 and 1772-1848 for the Polish region of Galicia is worth mentioning at this point. A successful continuation of this trend in research, from the point of view of economic history, is presented in the study entitled The History of the Climate of Galicia in the years 1848-1913 (Wnęk, 1999). The subtitle of this study is: The Impact of Meteorological Phenomena on the Socio-economic Development of Galicia. The author's decision to put meteorological phenomena first, indicates that such phenomena are far more destructive than other types of natural hazards. What is important, is that this study is based on instrumental data and emphasizes the climate's role in the nineteenth century society. It also shows the impact of the climate on plant production, price variations, and the mortality rate in Galicia.

The continuation of this trend in research is presented in the work of Zawora, who devised a calendar of meteorological conditions of the vegetation of crops in southeastern Poland in the years 1901-1990 (Zawora, 1993). The author of this study assigned intervals which are favorable or unfavorable in terms of excessive or insufficient precipitation, too high or too low temperatures and a combination of such elements, to each month of the vegetation period. This was possible thanks to the accounts provided by agricultural correspondents, who described the state of crops for each month of the vegetation period. The author treated this particular study as material for further climatic and agroclimatic studies. He did not carry out a periodization in the entire 90-year period either in terms of climatic or meteorological conditions of the vegetation of key crops. The presented study constitutes not only a continuation of studies by a 20-year extension period, (1991-2010) which is characterized by clear warming, but also provides a new viewpoint on climate conditions in this particular period and its impact on the meteorological conditions of vegetation. More recent research by other authors aim at being studies on the adaptation to climate extremes of some crop plant varieties, European varieties of wheat in particular (Mäkinen et al., 2018a,b; Kahiluoto et al., 2019). The forecasted climate, and environmental changes emphasise the need for plant breeding strategies which ensure both: a significant increase in crop potentials, and a resistance to extreme weather phenomena, such as heatwaves, late occurring frosts, and droughts (Stratonovitch and Semenov, 2015). It is noteworthy, that moderate climate areas with adequate conditions for vine cultivation are increasing (Machar et al., 2017).

The aim of this article, which simultaneously provides a new viewpoint on the studied period (110 years), is to present the frequency of both favorable and unfavorable meteorological conditions for key crops in the productive cycle in southeastern Poland. This analysis takes into account three different aspects: climate variability in selected time slices (1901-1930, 1931-1960, 1961-1990, 1971-2000 and 1981-2010), periods of wet-dry and warm-cool cycles, and, finally, an emphasis on the last 30 years, which are marked by a clearly increasing temperature trend (Kożuchowski and Żmudzka, 2001; IPCC, 2007; Żmudzka, 2009). 
The authors propose two scientific hypotheses which can be phrased as follows: 1 . The practical usability of climate studies, which are primarily based on standard values, can be limited by the periodicity of meteorological phenomena. 2 . The progressing global warming, during its initial phase, leads to the improvement of the meteorological conditions of vegetation, whilst in the next stage (especially recent years), leads to the increasing frequency of dry periods despite the lack of clear trends regarding precipitation totals.

\section{Materials and methods}

The principle materials used in this study featured agriculture correspondent bulletins about the state of cultivation (qualifying levels 1-5), as well as other reports pertaining to the meteorological conditions of the vegetation of key crops. It should be noted that the crops have not been divided into cultivated plants' categories such as: winter crops, spring crops, root crops and productive grassland. The majority of the above-mentioned bulletins and reports were drawn up at the end of each month, and were successively published over a longer period of time in a wide variety of statistical, agrometeorological, and agricultural journals (Biuletyn Agrometeorologiczny, Biuletyn Państwowej Służby Hydrologiczno-Meteorologicznej, Doświadczalnictwo Rolnicze, Gazeta Rolnicza, Kwartalnik Statystyczny, Miesięcznik Statystyczny, Miesięczny Przegląd Agrometeorologiczny, Rolnik, System Monitoringu Suszy Rolniczej w Polsce (SMSR), Tygodnik Rolniczy, Wiadomości Korespondenta Rolnego GUS, Wiadomości Meteorologiczne PIM). In their original form, they focused on the four main plant groups: winter crops, spring crops, root crops and productive grassland, which clearly differed in terms of both thermal and pluvial requirements. The relationships between the aforementioned groups of plants were standardized having in mind the methodological rule, which can be expressed in the following way: climate variability during individual vegetation periods is superior to the requirements of specific cultivate plants.

The climate data were gathered throughout a 110-year period (1901-2010) which was analyzed during the vegetation period only i.e. April-October. Accounts pertaining to the state of crops were assembled at the end of each month, hence every year 7 reports were drawn up. The bulletins always pertained to administrative units. However, it should be noted that administrative divisions were changed 6 times during the studied period. Therefore, the authors of this article tried to modify the reports about cultivation state so that they fit into the current area of the Subcarpathian voivodeship which was implemented on January 1, 1999. The studied area can be assigned to temperatetransient climate type, which is influenced by oceanic air masses and an increasing continental impact (Obrębska-Starklowa, 1977; Cebulak, 1992). In terms of the lie of the land, this area includes lowlands (the Sandomierz Basin), foothills and mountains (the Central and Eastern Beskid). The geographic coordinates of the extreme points are: $50^{\circ} 49^{\prime}-49^{\circ} 00^{\prime} \mathrm{N}$, and $21^{\circ} 09^{\prime}-23^{\circ} 33^{\prime} \mathrm{E}$ (Fig. 1).

According to correspondents' accounts which pertain to the state of the crops at the end of each month, the pluvio-thermal conditions were labeled either as favorable or unfavorable. Among the unfavourable conditions, there are: too low temperature, very low precipitation, excessive precipitation, too low temperature combined with excessive precipitation, very low temperature and precipitation, and finally very high temperature combined with insufficient precipitation. The classification of favorable and 
unfavorable pluvio-thermal conditions was based exclusively on the correspondents' accounts rather than on temperature or precipitation values (Zawora, 1993).

Apart from the calendar pertaining to meteorological conditions of vegetation of key crops, the authors also devised a pluvio-thermal calendar for the studied period (1901-2010), valid for vegetation period (April-October). They were mean area values for the studied area coming from 7 weather stations with long time observation stretches, taking into account the appropriate corrections resulting from the differences in the values of the meteorological elements, between the values from several weather stations, and from several dozens weather stations evenly distributed throughout the area. The homogeneity of the data was verified on the basis of two methods: difference stability (for temperature) and quotient stability (for precipitation).

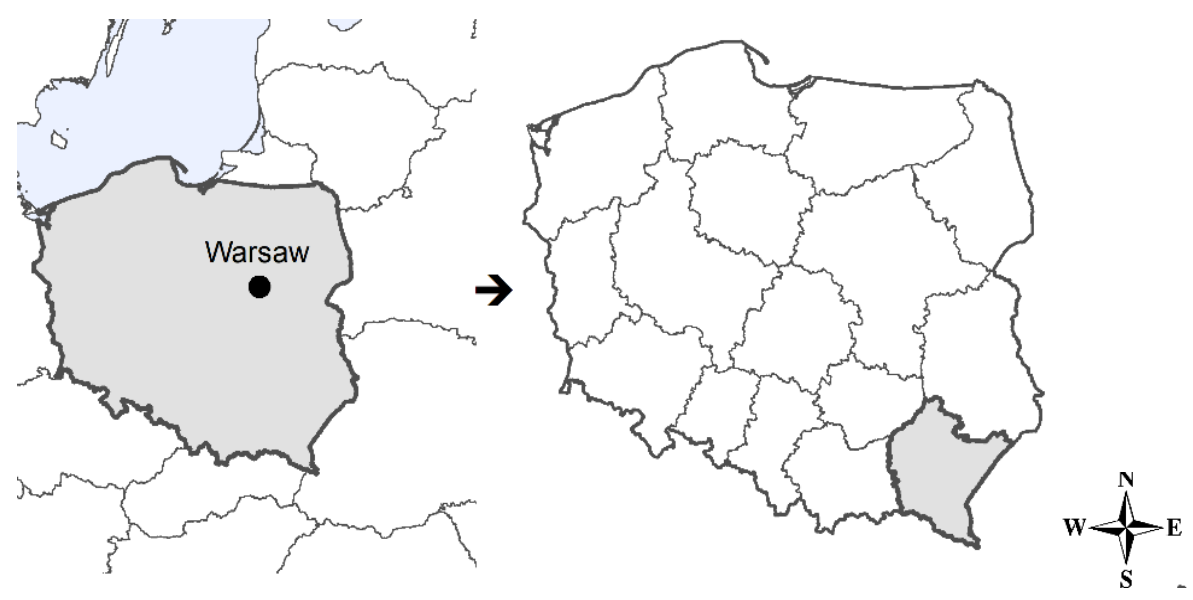

Figure 1. Area of investigations

The principle research method featured the comparison of the frequency of favorable and unfavorable pluvio-thermal conditions which pertain to the vegetation of key crops during the following climate normals: 1901-1930, 1931-1960, 1961-1990 and 1981-2010. The authors also carried out a comparison of the meteorological conditions and their changes over a longer period of time (such as 1901-1941 and 1942-1964). A detailed analysis of these changes and trends was included with reference to the last three decades (1981-2010), which is simultaneously the current climate normal, and a period of an intensified air temperature increase worldwide.

\section{Results}

In the period 1901-1930 favorable meteorological conditions for vegetation occurred with a $46 \%$ frequency. In the beginning of the vegetation period (April) such conditions were observed every three years. The primary limiting factors were very cold temperatures (20\%), frequently combined with excessive precipitation (20\%). Meteorological conditions during the vegetation period improved in the subsequent months, however they deteriorated again in September and October. In May, an important limiting factor were the dry conditions (23\%), while in July - excessive precipitation $(17 \%)$ often combined with very cold temperatures. In the remaining months one of the most unfavorable factors for the vegetation of plants was excessive precipitation (Table 1). 
The characteristics of the 1901-1930 period reveal that it was cold and wet compared to the subsequent 1931-1960 period. The temperature mean during the vegetation period was $12.7^{\circ} \mathrm{C}$ and the precipitation total equaled $532 \mathrm{~mm}(1901-1930)$. The subsequent 30 -year period was warmer and dryer. The vegetation period temperature mean reached $13.3^{\circ} \mathrm{C}$ and the precipitation total dropped to $496 \mathrm{~mm}$. This gradually improved the vegetation of key crops. Also the frequency of months with favorable pluvio-thermal conditions increased from 46 to 53\%. The percentage of very cold temperatures during April and May decreased by nearly half in the second 30-year period. In the month of June very cold temperatures were not observed during the 1931-1960 period. In general, the frequency of occurrence of dry months increased during the vegetation period from 15 to $20 \%$. In contrast, the frequency of excessive precipitation decreased from 16 to $12 \%$, and cases of excessive precipitation combined with too low temperature decreased by half (12 to 6\%, Tables 1 and 2).

Table 1. The frequency of occurrence of favorable and unfavorable pluvio-thermal conditions for the vegetation of key crops in southeastern Poland in the period $1901-1930(\%)$

\begin{tabular}{c|c|c|c|c|c|c|c|c|c}
\hline \multirow{2}{*}{ Meteorological conditions of vegetation } & \multicolumn{3}{|c}{ Month } \\
\cline { 2 - 8 } & IV & V & VI & VII & VIII & IX & X & IV-X \\
\hline Favorable thermal and pluvial conditions & 33 & 50 & 47 & 50 & 63 & 43 & 33 & 46 \\
Too low temperature & 20 & 7 & 10 & - & - & - & - & 5 \\
Insufficient precipitation & 7 & 23 & 10 & 13 & 7 & 27 & 20 & 15 \\
Excessive precipitation & 7 & - & 3 & 17 & 23 & 27 & 37 & 16 \\
Too low temperatures and excessive precipitation & 20 & 13 & 13 & 17 & 7 & 3 & 7 & 12 \\
Too low temperatures and insufficient precipitation & 7 & 7 & 10 & - & - & - & - & 3 \\
Too high temperatures and insufficient precipitation & 6 & - & 7 & 3 & - & - & 3 & 3 \\
\hline
\end{tabular}

Table 2. The frequency of occurrence of favorable and unfavorable pluvio-thermal conditions for the vegetation of key crops in southeastern Poland in the period $1931-1960(\%)$

\begin{tabular}{c|c|c|c|c|c|c|c|c}
\hline \multirow{2}{*}{ Meteorological conditions of vegetation } & \multicolumn{9}{|c}{ Month } \\
\cline { 2 - 8 } & IV & V & VI & VII & VIII & IX & X & IV-X \\
\hline Favorable thermal and pluvial conditions & 53 & 37 & 74 & 60 & 44 & 64 & 40 & 53 \\
Too low temperature & 10 & 3 & - & - & - & - & - & 2 \\
Insufficient precipitation & 7 & 17 & 17 & 23 & 30 & 23 & 23 & 20 \\
Excessive precipitation & - & - & 3 & 10 & 23 & 7 & 37 & 12 \\
Too low temperatures and excessive precipitation & 17 & 17 & 3 & - & 3 & 3 & - & 6 \\
Too low temperatures and insufficient precipitation & 3 & 10 & 3 & - & - & - & - & 2 \\
Too high temperatures and insufficient precipitation & 10 & 16 & - & 7 & - & 3 & - & 5 \\
\hline
\end{tabular}

The period $1961-1990$ with a mean temperature of $13.0^{\circ} \mathrm{C}$ is ranked between the first and second period. The precipitation total during the 1961-1990 period was $509 \mathrm{~mm}$ and was only $13 \mathrm{~mm}$ higher than during the previous period and $23 \mathrm{~mm}$ lower than during the 1901-1930 period. It should be noted, that the 1971-1980 decade was quite cold and wet. The meteorological conditions of vegetation deteriorated slightly compared with the previous 30-year period. Favorable meteorological conditions were 
observed during $50 \%$ of the time from April to October. In general, the frequency of occurrence of unfavorable conditions during the 1961-1990 period was intermediate compared to the cold and wet 1901-1930 period, and, the warm and dryer 1931-1960 period. Only the frequency of occurrence of cold months was similar to the 1901-1930 period. Specifically, April was not as cool as during the 1901-1930 period, whilst the frequency of very cold temperatures was observed from April until July. One of the features of this period is the lowest occurrence of very dry and extremely hot months compared to individual decades in the years 1901-1960 (Tables 1-3).

Table 3. The frequency of occurrence of favorable and unfavorable pluvio-thermal conditions for the vegetation of key crops in southeastern Poland in the period $1961-1990(\%)$

\begin{tabular}{c|c|c|c|c|c|c|c|c}
\hline \multirow{2}{*}{ Meteorological conditions of vegetation } & \multicolumn{3}{|c}{ Month } \\
\cline { 2 - 8 } & IV & V & VI & VII & VIII & IX & X & IV-X \\
\hline Favorable thermal and pluvial conditions & 38 & 53 & 54 & 56 & 57 & 50 & 43 & 50 \\
Too low temperature & 13 & 7 & 7 & 7 & - & - & - & 5 \\
Insufficient precipitation & 10 & 13 & 13 & 10 & 17 & 20 & 37 & 17 \\
Excessive precipitation & 13 & 3 & - & 10 & 20 & 30 & 20 & 14 \\
Too low temperatures and excessive precipitation & 13 & 17 & 20 & 17 & 3 & - & - & 10 \\
Too low temperatures and insufficient precipitation & 10 & 7 & 3 & - & 3 & - & - & 3 \\
Too high temperatures and insufficient precipitation & 3 & - & 3 & - & - & - & - & 1 \\
\hline
\end{tabular}

As noted at the beginning of this article, after 1961-1990, climate normals are changed every 10 years so they include for example periods: 1971-2000 and 1981-2010. The climate normal 1971-2000 should be omitted since it includes 20 years that overlap with each of the two above-mentioned periods. On the other hand, we should thoroughly analyze the recent 1981-2010 normal, since the last three decades were marked by an increasing warming occurring worldwide. In this particular period, the vegetation period temperature mean was highest $13.7^{\circ} \mathrm{C}$, whilst precipitation totals were identical as in the 1961-1990 period (509 $\mathrm{mm}$ ). A further improvement of meteorological conditions was observed during the vegetation period, and this fact was confirmed by a 57\% monthly increase in favorable conditions. This of course is the highest frequency among all the analyzed 30-year periods. On the other hand, the frequency of cold months decreased, especially in April and May. The frequency of occurrence of relatively dry months increased, especially in the case of dry months combined with extremely high temperatures. It should be emphasized, that the frequency of dry months with very high temperatures increased dramatically. During the previous 30-year periods, such months occurred sporadically, whilst in the 1981-2010 period they occurred in every month of the vegetation period. They occurred with most intensity during the summer months (10\% frequency, Table 4).

A very interesting aspect can be seen when we examine the evolution of meteorological conditions of vegetation in the period 1981-2010. As a rule, the closer we get to the end of the vegetation period, the more it turns out that the frequency of favorable meteorological conditions gradually decreases in the subsequent 30 -year periods (57, 55, 53\%, respectively). This is caused by the increasing frequency of dry periods, especially ones that are due to the increasing number of dry periods and, especially, to the occurrence of extreme temperature events (Table 5). 
Table 4. The frequency of occurrence of favorable and unfavorable pluvio-thermal conditions for the vegetation of key crops in southeastern Poland in the period $1981-2010(\%)$

\begin{tabular}{c|c|c|c|c|c|c|c|c}
\hline \multirow{2}{*}{ Meteorological conditions of vegetation } & \multicolumn{9}{|c}{ Month } \\
\cline { 2 - 8 } & IV & V & VI & VII & VIII & IX & X & IV-X \\
\hline Favorable thermal and pluvial conditions & 67 & 67 & 59 & 51 & 53 & 50 & 50 & 57 \\
Too low temperature & 7 & 3 & 7 & - & - & - & - & 3 \\
Insufficient precipitation & 10 & 13 & 13 & 13 & 24 & 17 & 23 & 16 \\
Excessive precipitation & 3 & 7 & 7 & 23 & 13 & 27 & 13 & 13 \\
Too low temperatures and excessive precipitation & 3 & 7 & 7 & 3 & - & 3 & 7 & 4 \\
Too low temperatures and insufficient precipitation & 7 & - & - & - & - & - & - & 1 \\
Too high temperatures and insufficient precipitation & 3 & 3 & 7 & 10 & 10 & 3 & 7 & 6 \\
\hline
\end{tabular}

Table 5. A comparison of the frequency of occurrence of favorable and unfavorable pluvio-thermal conditions during the vegetation of key crops in southeastern Poland in the periods: 1981-2010, 1991-2010 and 2001-2010 (\%)

\begin{tabular}{c|c|c|c}
\hline \multirow{2}{*}{ Meteorological conditions of vegetation } & \multicolumn{3}{|c}{ Period } \\
\cline { 2 - 4 } & $\mathbf{1 9 8 1 - 2 0 1 0}$ & $\mathbf{1 9 9 1 - 2 0 1 0}$ & $\mathbf{2 0 0 1 - 2 0 1 0}$ \\
\hline Favorable thermal and pluvial conditions & 57 & 55 & 53 \\
Too low temperature & 3 & 2 & 1 \\
Insufficient precipitation & 16 & 14 & 14 \\
Excessive precipitation & 13 & 17 & 19 \\
Too low temperatures and excessive precipitation & 4 & 3 & - \\
Too low temperatures and insufficient precipitation & 1 & - & - \\
Too high temperatures and insufficient precipitation & 6 & 9 & 13 \\
\hline
\end{tabular}

The comparison of the frequency of occurrence of favorable and unfavorable pluviothermal conditions of vegetation of key crops in the period 1901-1980 (before rapid warming) and 1981-2010 (rapid warming phase), indicates that the frequency varies at the significance level $\alpha=0,1 \%$ in the months April, May and July and at the significance level $1 \%$ in August. In June and September, the differences are not statistically significant.

\section{Discussion}

The analysis of the frequency of occurrence of favorable pluvio-thermal conditions enables us to calculate mean optimal temperature values and precipitation totals for the relevant months, as well as to designate optimal value intervals. The difference between mean values of meteorological components and their optimal values constitutes both deficits and surpluses in terms of precipitation totals and temperature. The second problem that can be solved here, (in other words: the second methodological approach) is the calculation of the aforementioned deficits and surpluses by employing natural climate cycles (occurrence of dry-wet or warm-cool conditions). The idea behind such type of analysis can be explained by the example mentioned below. 
During the post-war period a study was published, commissioned by the Main Spatial Planning Office, concerning the deficits and surpluses of atmospheric precipitation in individual Polish voivodeships (Hohendorf, 1948). The study period was 40 years long (1890-1930). Precipitation surpluses during the vegetation period in the former Rzeszów voivodeship equaled: for grains $(103 \mathrm{~mm})$, for beetroot $(65 \mathrm{~mm})$, for potatoes $(93 \mathrm{~mm})$, whilst for grassland there was a deficit equaled to $52 \mathrm{~mm}$. If we assume an equal area for all of the aforementioned crops, this gives us an average surplus of $52 \mathrm{~mm}$. Based on the analysis of data presented in the above-mentioned publication, the authors of this article suggest that the mean precipitation deficit for all studied crops in the period 1901-1941 (with optimal precipitation equal to $538 \mathrm{~mm}$ and $488 \mathrm{~mm}$ ) could be estimated at about 50 $\mathrm{mm}$. Therefore, this is the same order of magnitude as in Hohendorf's work, which, by the way, was conducted in a similar time period and in an area of about the same size.

If Hohendorf's research results had been used as indications for the planned irrigation projects, then the practical usage of this study comprised the post war years, which were marked by increasing levels of agrotechnics. In addition, this period was clearly marked by dry conditions (1941-1964). The precipitation total in the Rzeszów voivodeship equaled $455 \mathrm{~mm}$, but the optimal precipitation increased due to the increasing temperature and the increasing level of agrotechnics $(507 \mathrm{~mm})$. As a result, the precipitation deficit during the vegetation period dropped to $52 \mathrm{~mm}$. It should be noted, that during this period irrigation should have been employed instead of dehydration.

In this particular case, we are dealing with an adequate study assessment from a post factum perspective. This is due to the fact that a natural climate variability occurred after the study period, and we can expect possible consequences of these changes. Natural climate fluctuations also do not appear in elaborations that consist of data collected over long periods of time, as in the case of the aforementioned calendar of the meteorological conditions of key crops in southeastern Poland (Zawora, 1993). At present, when the anthropogenic factor of global warming is extensively mentioned in scientific studies, an assumption is made, that the analyses which pertain to present climate conditions need to be supplemented by basic climate forecasts (Górski, 2007; Górski and Kozyra, 2011).

There exist numerous scientific studies which present future visions of climate and selected causes of changes based on different climate change scenarios (IPCC, 2012, 2014a,b, 2018). The construction of such concepts is associated with a large degree of uncertainty, because each climate scenario is based on the fact that greenhouse gas emissions will increase depending on three factors: demographic development, implemented technology and assumed world economic development. At the same time, there is a large number of climate characteristics available, such as climate atlases that are based on past data, which are frequently out of date. This article attempts to eliminate such flaws, as well as present a description of contemporary agroclimate with reference to changes that have taken place since the beginnings of the twentieth century.

This study comprises simplifications, generalizations and shortcomings that can be supplemented in subsequent phases of this project. We can mention here such future suggestions as: the inclusion of the winter season, a variability analysis pertaining to yields of individual crop types (taking into account changing level of agrotechnics), the inclusion of meteorological conditions during field works, soil diversity, regional diversity of a given phenomenon. Conversely, a similar study or research could be carried out for individual physiographic regions or administrative units throughout Poland. 


\section{Conclusions}

1. Large natural climate variability, periodicity and climatic fluctuations enable us to claim that 30-year climate normals are not always a relevant period for climate characteristics in terms of performed and projected climate irrigation projects as well as adaptation activities in terms of unfavorable meteorological conditions and future climate change. Better results are obtained when we include natural periods of temperature and precipitation variability.

2. Progressing global warming has generally improved meteorological conditions of vegetation of major crops. The frequency of occurrence of favorable months has increased from $46 \%(1901-1930)$ to $57 \%$ in 1981-2010. The amelioration of meteorological conditions is mainly due to a decrease in the frequency of cool months and cool and wet months in the beginning of the vegetation period.

3. The last 30-year period (1981-2010), which is simultaneously the new obligatory climate normal as well as a period with a clear increase in temperature (with lack of precipitation trend) is marked by a gradual decrease in favorable conditions for vegetation and a simultaneous increase in unfavorable conditions caused by the increased frequency of excessive precipitation and dry periods (caused mainly by occurrence of extremely high temperatures).

Acknowledgements. The research was carried out under Project No. DS-3337/KEKiOP/2018 financed from a research grant allocated by the Ministry of Science and Higher Education.

\section{REFERENCES}

[1] Arguez, A., Vose, R. S. (2011): The Definition of the Standard WMO Climate Normal: The Key to Deriving Alternative Climate Normals. - Bulletin of the American Meteorological Society 92: 699-704.

[2] Bujak, F. (1976): Selection of Articles. - Madurowicz-Urbańska, H. (ed.) Warszawa. (in Polish).

[3] Cebulak, E. (1992): Maximum Daily Precipitation Totals in the Upper Vistula River Basin. - Zeszyty Naukowe UJ, Prace Geograficzne 90: 79-96. (in Polish).

[4] Górski, T. (2007): Changes in Poland's Agroclimatic Conditions Over the Last Century. - Papers on Global Change IG BP PAS 14: 55-67.

[5] Górski, T., Kozyra, J. (2011): Agroclimatic Normal of Air Temperature Mean in Poland in the Years 2011-2020. - Polish Journal of Agronomy 5: 21-28. (in Polish).

[6] Hohendorf, E. (1948): Precipitation Surpluses and Deficits in Poland. - Gospodarka Wodna 10: 276-287. (in Polish).

[7] IPCC. (2000): Emissions Scenarios. - A Special Report of IPCC Working Group III. Summary for Policymakers. Intergovernmental Panel on Climate Change.

[8] IPCC. (2007): Climate Change 2007. The Physical Science Basis. - Summary for Policymakers. Contribution of Working Group I to the Fourth Assessment Report of the Intergovernmental Panel on Climate Change.

[9] IPCC. (2012): Managing the Risks of Extreme Events and Disasters to Advance Climate Change Adaptation. - Field, C. B., Barros, V., Stocker, T. F., Dahe, Q. (eds.) https://doi. org/10.1017/CBO9781139177245.

[10] IPCC. (2014a): Climate Change 2014 Synthesis Report. - Retrieved from https://www.ipcc.ch/report/ar5/syr/. 
[11] IPCC. (2014b): Impacts, Adaptation, and Vulnerability. - Summary for Policymakers. Contribution of Working Group II to the Fifth Assessment Report of the Intergovernmental Panel on Climate Change. IPCC.

[12] IPCC. (2018): Global Warming of $1.5^{\circ} \mathrm{C}$. - Summary for Policymakers. An IPCC Special Report on the Impacts of Global Warming of $1.5^{\circ} \mathrm{C}$ Above Pre-industrial Levels and Related Global Greenhouse Gas Emission Pathways, in the Context of Strengthening the Global Response to the Threat of Climate Change. Retrieved from http://www.ipcc.ch/report/sr15/.

[13] Kahiluoto, H., Kaseva, J., Balek, J., Olesen, J. E., Ruiz-Ramos, M., Gobin, A., Kersebaum, K. C., Takáč, J., Ruget, F., Ferrise, R., Bezak, P., Capellades, G., Dibari, C., Mäkinen, H., Nendel, C., Ventrella, D., Rodríguez, A., Bindi, M., Trnka, M. (2019): Decline in Climate Resilience of European Wheat. - Proceeding of the National Academy of Science of the United States of America 116(1): 123-128.

[14] Kożuchowski, K., Żmudzka, E. (2001): Climate Warming in Poland: the Range and Seasonality of the Changes in Air Temperature in the Second Half of the $20^{\text {th }}$ Century. Przegląd Geofizyczny 46(1-2): 81-90. (in Polish).

[15] Křen, J. (1995): Production and Demand Trends of Small Grain Cereals in the Czech Republic. - Fragmenta Agronomica 2(46): 20-25.

[16] Livezey, R. E., Vinnikov, K. Y., Timofeyeva, M. M., Tinker, R., van den Dool, H. M. (2007): Estimation and Extrapolation of Climate Normals and Climatic Trends. - Journal of Applied Meteorology and Climatology 46: 1759-1776.

[17] Machar, I., Vlčková, V., Buček, A., Vrublová, K., Filippovová, J., Brus, J. (2017): Environmental Modelling of Climate Change Impact on Grapevines: Case Study from the Czech Republic. - Polish Journal of Environmental Studies 26(4): 1927-1934.

[18] Mäkinen, H., Kaseva, J., Trnka, M., Balek, J., Kersebaum, K. C., Nendel, C., Gobin, A., Olesen, J. E., Bindi, M., Ferrise, R., Moriondo, M., Rodríguez, A., Ruiz-Ramos, M., Takáč, J., Bezák, P., Ventrella, D., Ruget, F., Capellades, G., Kahiluoto, H. (2018a): Sensitivity of European Wheat to Extreme Weather. - Field Crops Research 222: 209-217.

[19] Mäkinen, H., Kaseva, J., Virkajärvi, P., Kahiluoto, H. (2018b): Gaps in the Capacity of Modern Forage Crops to Adapt to the Changing Climate in Northern Europe. Mitigation and Adaptation Strategies for Global Change 23(1): 81-100.

[20] Milly, P. C. D., Betancourt, J., Falkenmark, M., Hirsch, R. M., Kundzewicz, Z. W., Lettenmaier, D. P., Stouffer, R. J. (2008): Stationarity is Dead: Whither Water Management? - Science 319: 573-574.

[21] Motha, R. P., Baier, W. (2005): Impact of Present and Future Climate Change and Climate Variability on Agriculture in the Temperate Regions: North America. - Climatic Change 70: 137-164.

[22] Obrębska-Starklowa, B. (1977): Feno-climatic Regionalization and Typology Based on the Upper Vistula River Basin Example. - Rozprawy habilitacyjne UJ, 11. (in Polish).

[23] Solomon, S., Qin, D., Manning, M., Chen, Z., Marquis, M., Averyt, K. B., Tignor, M., Miller, H. L. (eds.) (2007): Climate Change 2007: The Physical Science Basis. Cambridge University Press, 996 pp.

[24] Stratonovitch, P., Semenov, M. A. (2015): Heat Tolerance Around Flowering in Wheat Identified as a Key Trait for Increased Yield Potential in Europe Under Climate Change. - Journal of Experimental Botany 66(12): 3599-3609.

[25] Wnęk, K. (1999): History of the Climate of Galicia in the Period 1848-1913: The Impact of Meteorological Phenomena on the Socio-economic Development of Galicia. - Historia Jagiellonica, Kraków. (in Polish).

[26] Zawora, T. (1993): Calendar of Meteorological Conditions Affecting Vegetation of the Cultivated Plants in Southeastern Poland Over 1901-1990. - Zeszyty Naukowe UJ, Prace Geograficzne 95: 223-227. (in Polish).

[27] Żmudzka, E. (2009): Contemporary Changes of Climate of Poland. - Acta Agrophysica 13(2): 555-568. (in Polish). 